\title{
NOTES AND COMMENTS \\ Correspondence Between Sir Robert Jennings AND KEITH HighET
}

Editor's Note: Judge Jennings and Mr. Highet have agreed to share this private letter from the former to the latter sent in response to notification of his honorary membership in the Society. We thought it would be of some interest to the general membership and to historians.

\section{Dear Keith,}

I am writing to thank you most warmly for your kind letter of April 19th about my honorary membership of the A.S.I.L.

May I also say again how very much I appreciate this honour? You may be interested to know how it was that $I$ have been a member for so long. When, after returning from six years in the Army during W.W.II, I returned to Cambridge, I quickly came under the influence of Hersch Lauterpacht, who became one of the closest friends I have ever had. One of his earliest pieces of advice was: "You cannot pretend to be a serious scholar of international law, unless you subscribe to the American Journal; so take my advice and do that straight away."

I did!

With renewed thanks, and best personal regards, Yours sincerely,

\section{ROBBIE}

\section{A Note TO OUR READERS}

Because of space constraints in the Journal, a response by John Norton Moore to Rowles, "Secret Wars," Self-Defense and the Charter-A Reply to Professor Moore (80 AJIL 568 (1986)), is being published in the March/April 1987 issue of the Virginia Journal of International Law (vol. 27, No. 2).

\section{CORRESPONDENCE}

The American Journal of International Law welcomes short communications from its readers. It reserves the right to determine which letters should be published and to edit any letters printed. Letters should conform to the same format requirements as other manuscripts.

TO THE EDITOR IN CHIEF:

September 3, 1986

Professor Glennon's brief Editorial Comment, Mr. Sofaer's War Powers "Partnership" (80 AJIL 584 (1986)), appears hurried, heated, tendentious, and a bit naive. 